\title{
任意の釷配列で打たれた面材壁の終局耐力の算定理論式 \\ - 理論值と回帰值の比較 - \\ THEORETICAL FORMULA TO PREDICT THE ULTIMATE SHEAR CAPACITY OF SHEATHED SHEAR WALLS WITH ANY NAILING ARRANGEMENT PATTERN
}

Comparison between values calculated from theoretical equations and regression equations

\author{
村上 雅 英*1
}

\section{Masahide MURAKAMI}

\begin{abstract}
The formula for the full plastic nail arrangement modulus $Z_{p x y}$ which is used in the calculation of the ultimate shear capacity of the sheathed shear walls with any nail arrangement was theoretically derived by using the upper bound theorem. The unknown values are the rotation ratio $\left(\theta_{x} / \theta_{y}\right)$ and the neutral axis positions $\left(x_{o}\right.$ and $\left.y_{o}\right)$ in the calculation. The difference between the calculation with the elastic values and the plastic values as unknown values is within $1.5 \%$.
\end{abstract}

Keywords : Sheathed shear wall, Ultimate shear capacity, Upper bound theorem, Numerical analysis, Nailing pattern 面材張り大壁，終局せん断耐力，上界定理，数值解析，釷配列

\section{1. はじめに}

筆者が提案した任意の釘配列で打たれた面材壁の弾塑性挙動を推 定するための計算理論 ${ }^{1}$ ( は、接合具のせん断性状を完全弾塑性に置 換することで、剛性、降伏耐力、終局耐力、勒性など構造設計に必 要な情報が定式化 (以下、算定式)されているため、木質構造の構造 設計2)で不可欠な基本理論として、現在では広く用いられている。

研究分野においても弾塑性数值解析と算定式の比較も行われ、降 伏耐力まではつり合い式に基づいた力学理論で定式化されているた め、よく一致することが確認されている。しかしながら、終局耐力 の算定式は、つり合い式によるアプローチでは定式化が不可能で あったため、数值解析によるパラメトリックスタディに基づいて安 全側になるように回帰式で構成されている。

近年の数值解析ソフトの普及に伴い、面材に打たれた釘（以下、 単に釘とよぶ)の円形降伏曲面をM.S.S.モデルで表現することで、 面材壁の弾塑性解析が容易にできるようになってきた例えば3)。その ような社会状況を鑑みて、算定式による終局耐力の予測精度を向上 させることが課題であった。

そこで、本研究では、従来、回帰式で構成していた面材大壁の全 塑性抵抗モーメント $M_{p}$ の算定式の予測精度を向上させると共に、 弾性〜終局までの全ての算定式を力学理論で完結させることを目的 とする。

\section{2. 既往の研究と理論式作成のアプローチ}

面材の四周を釬打ちした大壁のせん断力-変形角関係を推定する ための理論アプローチには、Toumi R.L.4)によるエネルギー法と、 神谷5による力のつり合いの方法がある。別の観点から既往の研究 を概観すると、文献 1 以外の寸べての研究では、Toumi R.L.の研 究手法に倣い、釘の $P-\delta$ 曲線の縦軸と横軸に弾性時の計算から求め た係数を乗じることで、面材壁のせん断力一変形角曲線を求めるこ とを目的としており、筆者が行っているような設計実務に必要な降 伏耐力や終局耐力の定式化は行われていない。

既往の研究のエネルギー法によるアプローチでは、剛体と仮定し た面材の隅角部の釘の滑り量は、ピン接合された剛体の枠材に水平 力が作用して変形した平行四辺形の対角線の方向に一致すると変位 の適合条件を近似して、各釘に蓄えられる弾性エネルギーの算出を 行っている。当然のことながら、そのように仮定した滑り量に基づ いて各釷に作用するせん断力を、X方向とY方向の分力に分解して 各方向の抵抗モーメントを求めると、力のつり合いは成立しない。 しかしながら、変形の適合条件を満たしているので、上界定理より 計算結果は正解に近くなる。このことに注目すると、エネルギー法 を用いることで、全塑性状態のつり合い条件を満たす変形状態でな くても、変形の適合条件を満たすように各釷の滑り量を適切に仮定 すれば、全塑性抵抗モーメント $M_{p}$ が容易に理論的に定式化でき る。更に、任意の釷配列に対する変形の適合条件を満たすような各 釷の滑り量の算定は、筆者の提案した計算理論に基づいた弾性域の 


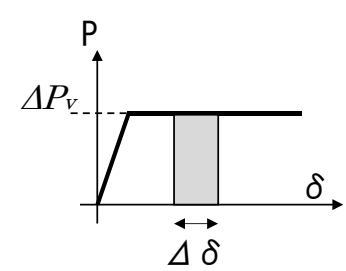

Fig.1 Shear behavior of nails

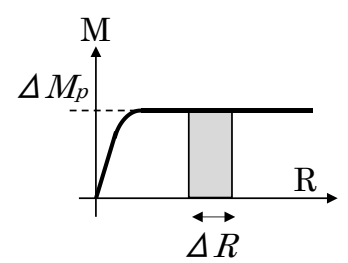

Fig. 3 Work done of external moment

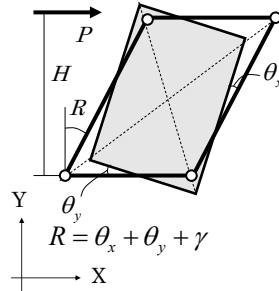

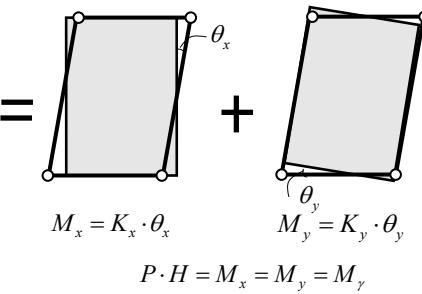

$P \cdot H=M_{x}=M_{y}=M_{\gamma}$

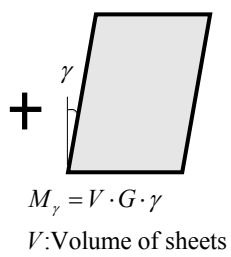

$V:$ Volume of sheets

Fig.2 Deformation decomposition of sheathed shear walls

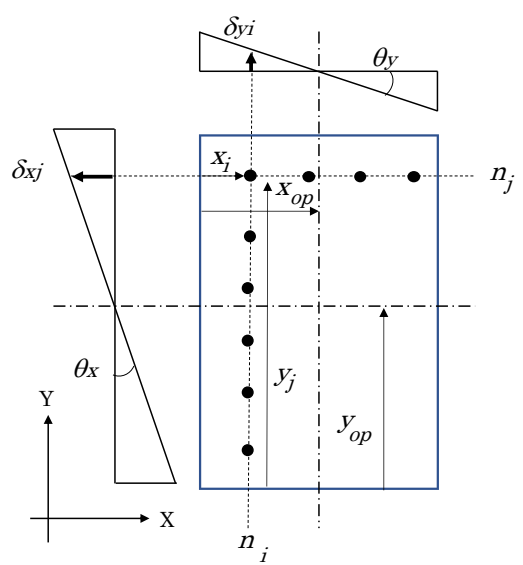

Fig.4 Shear deformation of ij-th nail
算定式1)を用いることで、容易に求めることができる。したがっ て、両者を組み合わせることで、任意の釗配列に対して全塑性抵抗 モーメント $M_{p}$ を算定するための理論式の構築が可能となる。

\section{3. 全塑性抵抗モーメントの理論式の誘導}

仮定は、以下のとおりとする注1)。

1. 面材はせん断変形のみを考慮した弾性体として扱う。

2. 枠材の曲げ変形、せん断変形、軸方向変形は無視する。また、 各枠材の接合はピン接合とする。

3. 釷のせん断性状は、Fig.1に示すように完全弹塑性と仮定する。 仮定の 1 と 2 基づくと、Fig. 2 に示すように、真のせん断変形角 $R$ は、X方向とY方向のそれぞれの回転角 $\theta_{x}$ と $\theta_{y}$ おび面材のせん断 変形角 $\gamma$ の和となり、それぞれの変形に必要な外力モーメントは等 しく、それらは直列の関係で表される。全ての釘が塑性状態になる と、変位増分 $\Delta R$ に対する外力モーメントのなす仕事はFig.3のよう に $M_{p} \cdot \Delta R$ となり、各釘に蓄えられる塑性エネルギーはFig.1のよう に $\Delta P_{v} \cdot \Delta \delta_{i j}$ となる。従って、上界定理より、式(1)が導かれる。

$$
M_{p} \cdot \Delta R=\sum \Delta P_{v} \cdot \Delta \delta_{i j}
$$

全塑性状態では、外力は一定值となるため、面材のせん断変形の 増分 $\Delta \gamma$ 性じないので、Fig. 2 に示す変形の適合条件は式(2)で表さ れる。

$\Delta R=\Delta \theta_{x}+\Delta \theta_{y}$

一方、Fig.4よりX方向とY方向の $i$ 番目の釘の滑り量は、 $\theta_{x}$ と $\theta_{y}$ を 用いて、式(3)で表される。

$$
\begin{aligned}
& \delta_{x j}=\left(y_{j}-y_{o p}\right) \cdot \theta_{x} \\
& \delta_{y i}=\left(x_{i}-x_{o p}\right) \cdot \theta_{y}
\end{aligned}
$$

ここで、 $x_{i} 、 y_{j}$ は $i j$ 番目の釗の座標、 $x_{o p} 、 y_{o p}$ は、全塑性状態での各 方向の中立軸位置

$\Delta \theta_{x}=\alpha_{x} \cdot \Delta R$ と置くことで、ij番目の釷の滑り量のX方向とY方向の 増分 $\Delta \delta_{x i} 、 \Delta \delta_{y i}$ と真のせん断変形角 $\Delta \mathrm{R}$ の関係式が、式(3)より式 (4)
のように得られる。

$$
\begin{aligned}
\Delta \delta_{x j} & =\left(y_{j}-y_{o p}\right) \cdot \alpha_{x} \cdot \Delta R \\
\Delta \delta_{y i} & =\left(x_{i}-x_{o p}\right) \cdot\left(1-\alpha_{x}\right) \cdot \Delta R
\end{aligned}
$$

$i j$ 番目の釘の滑り量の増分 $\Delta \delta_{i j}$ は、、式(5)で表される。

$$
\Delta \delta_{i j}=\sqrt{\Delta \delta_{x j}^{2}+\Delta \delta_{y i}^{2}}
$$

式(5)を式(1)に代入することで、 $M_{p}$ の理論式が式(6)のように導か れる。

$M_{p}=\Delta P_{v} \cdot \sum \sqrt{\left\{\left(y_{j}-y_{o p}\right) \cdot \alpha_{x}\right\}^{2}+\left\{\left(x_{i}-x_{o p}\right) \cdot\left(1-\alpha_{x}\right)\right\}^{2}}=\Delta P_{v} \cdot Z_{p x y}$

ここで、 $Z_{p x y}$ は全塑性釘配列係数

式 (6)においての未知数は、全塑性状態時の $\alpha_{x}$ と中立軸位置 $X_{o p}$ と Yopであり、それらは変形の適合条件を満たしつつ適切に仮定する 必要がある。そこで、それらの未知数を弾性時の值を用いること で、各未知数は以下のように求まる。

弾性時の中立軸位置 $x_{o}$ と $y_{o}$ は、式(7)で与えられる。

$x_{o}=\frac{\sum x_{i} \cdot n_{i}}{\sum n_{i}}$

$y_{o}=\frac{\sum y_{j} \cdot n_{j}}{\sum n_{j}}$

ここで、 $n_{i}$ と $n_{j}$ は、各行または列の釘の本数

$\mathrm{X}$ 方向とY方向の釘の配列 2 次モーメント $I_{x}$ と $I_{y}$ は、式(8)で与えられ る。

$I_{x}=\sum\left(y_{j}-y_{o}\right)^{2} \cdot n_{j}$

$I_{y}=\sum\left(x_{i}-x_{o}\right)^{2} \cdot n_{i}$

$\mathrm{X}$ 方向とY方向の釘の抵抗モーメント $M_{x}$ と $M_{y}$ は、釷の剛性 $k$ を用 いて、式(9)で与えられる。

$M_{x}=k \cdot I_{x} \cdot \theta_{x}$
$M_{y}=k \cdot I_{y} \cdot \theta_{y}$

両者は直列の関係にあり、 $M_{x}=M_{y}$ より、式(10)を得る。 
$\frac{\theta_{x}}{\theta_{y}}=\frac{I_{y}}{I_{x}}$

(10)

式(10)を式(2)に代入することで、式(11)を得る。

$$
\begin{aligned}
& \theta_{x}=R \cdot \alpha_{x} \\
& \theta_{y}=R \cdot\left(1-\alpha_{x}\right) \\
& \text { ここで } \\
& \quad \alpha_{x}=\frac{I_{y}}{I_{x}+I_{y}}=\frac{\theta_{x}}{\theta_{x}+\theta_{y}}
\end{aligned}
$$

\section{4. 理論式と回帰式の比較}

\section{1 回帰式の概要}

3 章で誘導した理論式と文献1で提案した回帰式との比較をする ことで、理論式が回帰式よりも優れていることを示す。比較対象と する回帰式を以下に示す。

全塑性状態の時のX方向とY方向の抵抗モーメント $M_{p x}$ と $M_{p y}$ は、 式(13)で表される。

$$
\begin{aligned}
& M_{p x}=\Delta P_{v} \cdot \sum \frac{\left(y_{j}-y_{o p}\right)^{2} \cdot \theta_{p x}}{\sqrt{\left(x_{i}-x_{o p}\right)^{2} \cdot \theta_{p y}^{2}+\left(y_{j}-y_{o p}\right)^{2} \cdot \theta_{p x}^{2}}} \\
& M_{p y}=\Delta P_{v} \cdot \sum \frac{\left(x_{i}-x_{o p}\right)^{2} \cdot \theta_{p y}}{\sqrt{\left(x_{i}-x_{o p}\right)^{2} \cdot \theta_{p y}^{2}+\left(y_{j}-y_{o p}\right)^{2} \cdot \theta_{p x}^{2}}}
\end{aligned}
$$

両者は直列の関係であるので、常に式(14)を成立させる必要があ り、そのためには、全塑性状態の時の中立軸位置 $x_{o p}$ と $y_{o p}$ 、および $\mathrm{X}$ 方向とY方向の回転角比 $\left(\theta_{p x} / \theta_{p y}\right)$ を適切に設定する必要がある。

$$
M_{p x}=M_{p y}
$$

文献 1 では、 $W=91 \sim 273 \mathrm{~cm} 、 H=30 \sim 273 \mathrm{~cm}$ の面材寸法を対象 に、釘間隔、間柱間隔、外周に対する間柱の釷間隔の比、および四 周釷配列、川の字釷配列、X軸に対してのみ非対称とした山の字釷 配列を変数とした759通りに対して、式(13)と(14)を満たすように 収斂計算で $y_{o p}$ と $\theta_{p x} / \theta_{p y}$ を決めて、 $M_{p}$ の正解值を算出した。そし て、弾性時の $\theta_{x} / \theta_{y}$ と中立軸位置から全塑性時の值を推定するため に、回帰式である式(15) と式(16)を作成した。式(15) と式(16)で 得られた值を用いて式(13)を算出しても、式(14)は成立しない。 そこで、 $M_{p x}$ と $M_{p y}$ の平均值と正解值との比率 $Y_{e r r}$ を求めると、式 (17)で回帰できることが見いだされ、その逆数を乗じることで、 $M_{p}$ が式(18)のように算出できる。

$$
\mathrm{Iy} \geqq \mathrm{Ix} \text { のとき } \quad \frac{\theta_{p x}}{\theta_{p y}}=1.28458 \frac{I_{y}}{I_{x}}=1.28458 \frac{\theta_{x}}{\theta_{y}}
$$

$\mathrm{Iy}<\mathrm{Ix}$ のとき $\quad \frac{\theta_{p x}}{\theta_{p y}}=\frac{I_{y}}{1.28458 \cdot I_{x}}=\frac{\theta_{x}}{1.28458 \cdot \theta_{y}}$

ここで、 $\theta_{x} / \theta_{y}$ は弾性時のX方向とY方向の回転比率

$y_{o p}=-0.1059 \cdot H+1.2118 \cdot y_{o}$

ここで、yop と $y_{0}$ はそれぞれ全塑性状態と弾性状態の中立軸位置
$Y_{\text {err }}=0.99774+0.06793 \cdot X_{e r r}+0.90613 \cdot X_{e r r}^{2}$

ここで、 $\quad X_{e r r}=\frac{2 \cdot\left|M_{p x}-M_{p y}\right|}{M_{p x}+M_{p y}}$

$$
M_{p}=\Delta P_{v} \cdot Z_{p x y}=\frac{M_{p x}+M_{p y}}{2 \cdot Y_{e r r}}
$$

式(18)が正解值を上回る確率は約50\%であることから、式(18)に 0.9411を乗じることで、正解值の母数に対しての $5 \%$ 下限值が得ら れる。

\section{2 理論式と回帰式の比較}

比較対象とする釷配列の一覧と理論值と回帰式による計算值の比 較を、Fig. 5 とTable 1に示す。次節で述べるように未知数 $\alpha_{x}$ と中立 軸位置を弾性時の值で理論值の算出しても、誤差が $1.5 \%$ 以下と極 めて少ないことから、その值を記している。釷配列は「四周釷配列

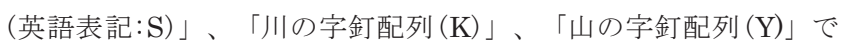
あり、図中の $H$ と $W$ は両端の釷の距離である。また、間柱の釷は面 材の中心から両端に向けて、枠材周囲に打つ釘間隔の2倍の間隔で 割り付けている。No.16と17は間柱がない。 $3 \times 10$ 版の面材を耐力 壁に使用することを考慮して、四周釷打ちの検証対象とする面材の 縦横 $(H / W)$ 比は、1.0 3.33の範囲とする。なお、回帰式で算出さ れた $Z_{p x y}$ の值は式(18)より求めており、50\%下限值に相当する。

No.1は、理論式がつり合い式を満たしていることを回帰式より 検証するためのモデルであり、全塑性状態でも中立軸の移動がな く、 $\theta_{x} / \theta_{y}=\theta_{p x} / \theta_{p y}=1.0$ となる釷配列、寸なわち正方形の面材で外周 のみに等間隔の釷配列であるため、式(15)を用いずに注.2)計算して おり、 $X_{e r r}=0$ となるため式(17)で $Y_{\text {err }}=1.0$ としている。理論式と回 帰式でそれぞれ算出された $M_{p}$ は完全に一致しており、また、回帰 式において $X_{e r r}=0$ であることから、理論式で得られた $M_{p}$ がつり合い 式を満たしていることが確認できる。

No.2〜15は、実務で多用される定尺の面材を基本とした釷配列 である。現実的な釘間隔、釷配列、 $H / W$ こ対しては、理論式に対す る回帰式の $Z_{p x y}$ の比率は土5\%以内である。そこで、回帰式では、過 大評価となる釷配列に対して、5\%下限值を設定する必要があり、 低減率0.9411を乗じている。そのため、実際に使用寸る面材の釷配 列によっては、低減率を乗じると回帰式による $Z_{p x y}$ は、理論值に対 して最大で約 $10 \%$ 過少評価されているものも存在する。

No.17は、回帰式のもととなった正解值を得るための解析変数の うち、正解值に対する精度が極めて悪い釷配列の例である。 $I_{x}$ と $I_{y}$

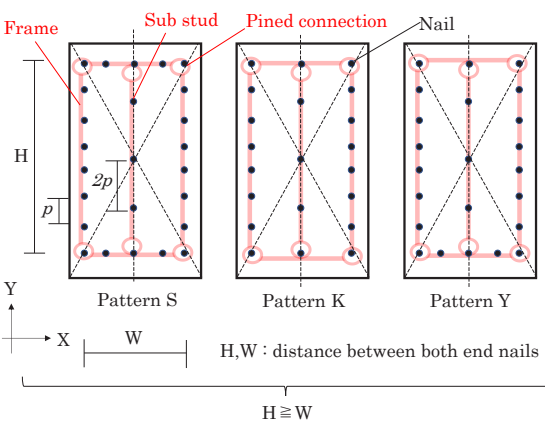

Fig.5 Nailing patterns

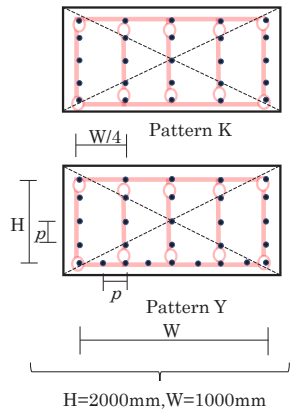

$\mathrm{H}=2000 \mathrm{~mm}, \mathrm{~W}=1000 \mathrm{~mm}$ 
Table 1 Model Parameters and results

\begin{tabular}{|c|c|c|c|c|c|c|c|c|c|c|c|c|c|}
\hline \multirow{2}{*}{ No. } & \multirow{2}{*}{ Model name } & \multirow{2}{*}{$\begin{array}{c}W \\
(\mathrm{~mm})\end{array}$} & \multirow{2}{*}{$\begin{array}{c}H \\
(\mathrm{~mm})\end{array}$} & \multirow{2}{*}{$\begin{array}{c}p \\
(\mathrm{~mm})\end{array}$} & \multirow{2}{*}{ pattern } & \multicolumn{3}{|c|}{$Z p_{x y}(\mathrm{~cm})$} & \multirow{2}{*}{$\alpha x$} & \multirow{2}{*}{$y o / H$} & \multirow{2}{*}{ Xerr } & \multirow{2}{*}{$\begin{array}{l}\text { R.Eq. } \\
\text { Eq.(6) }\end{array}$} & \multirow{2}{*}{$\frac{\text { N.A }}{\text { Eq.(6) }}$} \\
\hline & & & & & & Eq.(6) & R.Eq. & N.A. & & & & & \\
\hline 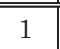 & S9x9@10N & \multirow{13}{*}{900} & \multirow{4}{*}{900} & \multirow{4}{*}{100} & SN & 932 & 932 & 932 & 0.500 & 0.500 & 0.000 & $\begin{array}{l}1.000 \\
\end{array}$ & 1.000 \\
\hline 2 & S9x9@10 & & & & $\mathrm{S}$ & 990 & 996 & 987 & 0.480 & 0.500 & 0.033 & 1.006 & 0.997 \\
\hline 3 & K9x9@10 & & & & $\mathrm{K}$ & 549 & 562 & 536 & 0.664 & 0.500 & 0.016 & 1.025 & 0.977 \\
\hline 4 & Y9x9@10 & & & & $\mathrm{Y}$ & 758 & 737 & 577 & 0.577 & 0.379 & 0.108 & 0.973 & 0.762 \\
\hline 5 & S9x18@5 & & \multirow{5}{*}{1800} & 50 & $\mathrm{~S}$ & 3828 & 3865 & 3810 & 0.244 & 0.500 & 0.089 & 1.010 & 0.995 \\
\hline 6 & S9x18@15 & & & 150 & $\mathrm{~S}$ & 1266 & 1275 & 1255 & 0.250 & 0.500 & 0.057 & 1.007 & 0.991 \\
\hline 7 & S9x18@10 & & & \multirow{11}{*}{100} & $\mathrm{~S}$ & 1924 & 1944 & 1917 & 0.242 & 0.500 & 0.100 & 1.010 & 0.996 \\
\hline 8 & K9x18@10 & & & & $\mathrm{K}$ & 1457 & 1376 & 1447 & 0.358 & 0.500 & 0.160 & 0.944 & 0.993 \\
\hline 9 & Y9x18@10 & & & & $\mathrm{Y}$ & 1697 & 1669 & 1583 & 0.296 & 0.427 & 0.038 & 0.984 & 0.948 \\
\hline 10 & S9x27@10 & & \multirow{3}{*}{2700} & & $\mathrm{~S}$ & 2803 & 2874 & 2496 & 0.143 & 0.500 & 0.201 & 1.025 & 0.868 \\
\hline 11 & K9x27@10 & & & & $\mathrm{K}$ & 2373 & 2352 & 2338 & 0.206 & 0.500 & 0.025 & 0.991 & 0.985 \\
\hline 12 & Y9x27@10 & & & & $\mathrm{Y}$ & 2595 & 2626 & 2496 & 0.171 & 0.448 & 0.078 & 1.012 & 0.962 \\
\hline 13 & S9x30@10 & & 3000 & & $\mathrm{~S}$ & 3099 & 3190 & 3055 & 0.122 & 0.500 & 0.253 & 1.029 & 0.986 \\
\hline 14 & K20x10@10 & \multirow{2}{*}{2000} & \multirow{2}{*}{1000} & & $\mathrm{~K}$ & 1452 & 1513 & 1439 & 0.833 & 0.500 & 0.123 & 1.042 & 0.991 \\
\hline 15 & Y20x10@10 & & & & $\mathrm{Y}$ & 2054 & 2055 & 1484 & 0.792 & 0.387 & 0.035 & 1.001 & 0.723 \\
\hline 16 & S3x27@10 & \multirow{2}{*}{300} & \multirow{2}{*}{2700} & & $\mathrm{SN}$ & 851 & $837^{*}$ & 831 & 0.028 & 0.500 & 0.033 & 0.984 & 0.977 \\
\hline 17 & K3x27@10 & & & & $\mathrm{KN}$ & 826 & $685^{* *}$ & 802 & 0.033 & 0.500 & 0.257 & 0.830 & 0.971 \\
\hline
\end{tabular}

R.Eq. : Equations obtained by regression analysis, N.A. : Numerical analysis

Pattern SN : Nailed only along perimeter of a sheeet, KN : Nailed along longitudinal edges

* Zxy of S3x27@10 is $819 \mathrm{~cm}>788 \mathrm{~cm}=0.9411 \mathrm{x} 837 \mathrm{~cm}$. ** Zxy of K3x27@10 is $802 \mathrm{~cm}>685 \mathrm{~cm}$.

$* * *$ The numerical Analysis could not be correctly excuted.

Table 2 Influence of unknown values (Unit:cm)

(a) Effect of variation in $\alpha_{x}$ only

(No.7) S9x18@10

\begin{tabular}{c|c|c|c}
\hline$\alpha x$ & $Z p x y$ & Ratio & \\
\hline \hline 0.100 & 1926 & 1.001 & \\
0.174 & 1907 & 0.991 & N.A. \\
0.199 & 1910 & 0.992 & Plastic \\
0.200 & 1910 & 0.992 & \\
0.242 & 1924 & 1.000 & Elstic \\
0.300 & 1963 & 1.020 & \\
0.400 & 2077 & 1.079 & \\
0.500 & 2243 & 1.165 & \\
\hline
\end{tabular}

(No.8) K9x18@10

\begin{tabular}{c|c|c|c}
\multicolumn{4}{c}{ (No.8) K9x18@10 } \\
\hline \hline$\alpha x$ & $Z p x y$ & Ratio & \\
\hline 0.100 & 1593 & 1.093 & \\
0.200 & 1509 & 1.035 & \\
0.300 & 1464 & 1.005 & \\
0.303 & 1464 & 1.004 & Plastic \\
0.332 & 1459 & 1.001 & N.A. \\
0.358 & 1457 & 1.000 & Elstic \\
0.400 & 1462 & 1.003 & \\
0.500 & 1500 & 1.029 & \\
\hline \multicolumn{4}{|c}{}
\end{tabular}

(No.13) S9x30@10

\begin{tabular}{c|c|c|c}
\hline$\alpha x$ & $Z p x y$ & Ratio & \\
\hline \hline 0.076 & 3058 & 0.987 & N.A. \\
0.097 & 3072 & 1.000 & Plastic \\
0.100 & 3074 & 0.992 & \\
0.122 & 3099 & 1.000 & Elstic \\
0.200 & 3266 & 1.054 & \\
0.300 & 3622 & 1.169 & \\
0.400 & 4100 & 1.323 & \\
0.500 & 4670 & 1.507 & \\
\hline
\end{tabular}

(No.11) K9x27@10

\begin{tabular}{c|c|c|c}
\hline$\alpha x$ & $Z p x y$ & Ratio & \\
\hline \hline 0.087 & 2407 & 1.014 & N.A. \\
0.100 & 2396 & 1.010 & \\
0.168 & 2368 & 0.998 & Plastic \\
0.200 & 2372 & 0.999 & \\
0.206 & 2373 & 1.000 & Elstic \\
0.300 & 2448 & 1.032 & \\
0.400 & 2614 & 1.101 & \\
0.500 & 2853 & 1.202 & \\
\hline
\end{tabular}

(b) Effect of variation in $y_{0}$ and $\alpha_{x}(($ No.15) Y20x10@10)

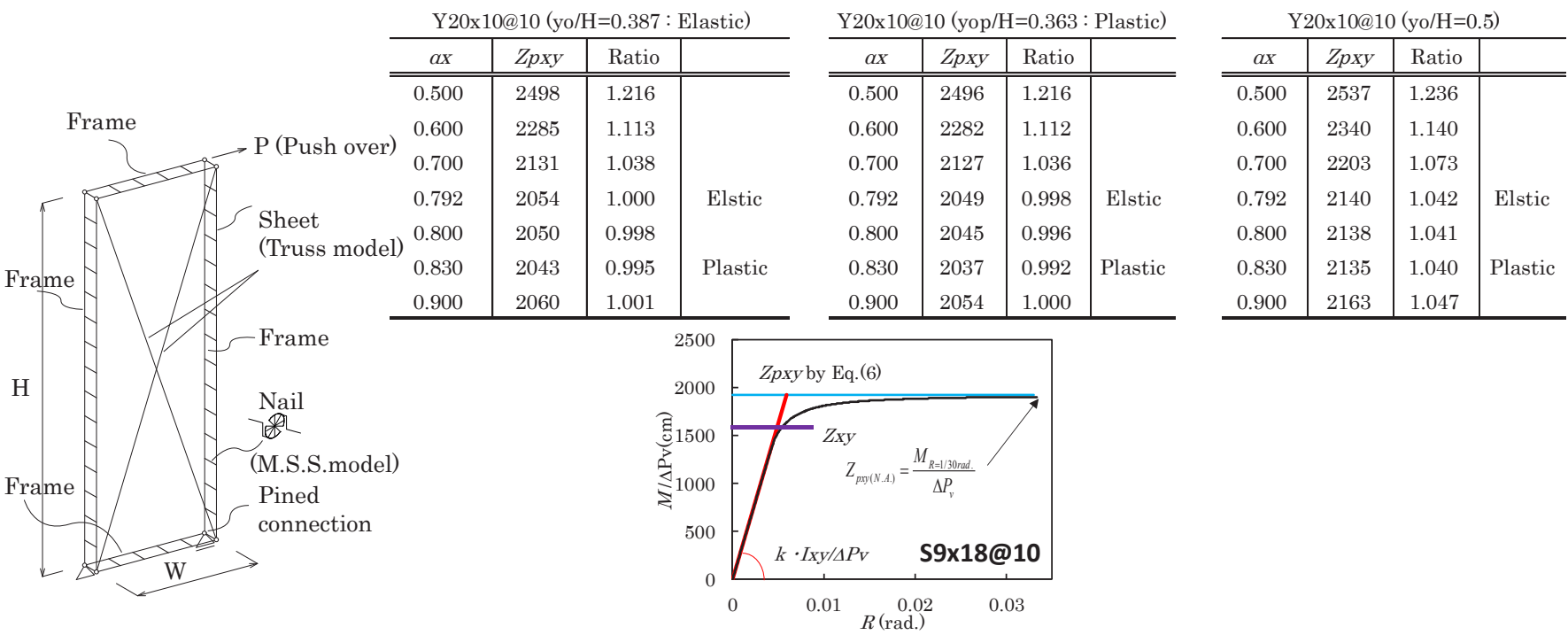

Fig.6 Model for numerical analyses 
の差が極端に大きく、かつ $X_{\text {err }}$ の值が大きい例であり、回帰式によ る $Z_{p x y}$ は $Z_{x y}$ (釷の配列係数1 $\left.{ }^{2}\right)$ ) を下回っており、明らかに矛盾してい る。No.16は低減率0.9411を乗じると $Z_{x y}$ を下回る例である。このよ うに少数ではあるが、回帰式ゆえの問題のある釘配列が存在する。

参考值として、弾塑性解析ソフトSNAP Ver.7を用いて、30度毎 にせん断バネを設け、任意角度のせん断力に対して一様な降伏局面 を有するM.S.S.モデルで釘の降伏を表現したFig.6に示すような解 析モデルによる数值解析結果も示寸。面材はFig.6のように線材で トラス置換している。両端の釘の距離 $H$ とWの寸法で枠材を線材で モデル化した。また、外周以外で釷を打っている間柱と枠材とは、

Fig.5の赤で示しているようにピン接合されている。モデル化に際 して、枠材と面材を表現している全ての線材は、釷の剛性／間隔と 比べて十分剛とみなせる值 $\left(E A=10^{15} \mathrm{~N} 、 E I=10^{20} \mathrm{Nmm}^{2}\right.$ 、 $\left.G A=10^{13} \mathrm{~N}\right)$ で設定している。釷のせん断性状は、比較の容易さを 考慮して、N50の值に近い $k=0.5 \mathrm{kN} / \mathrm{mm} 、 \Delta P_{v}=1 \mathrm{kN}$ とし、第 2 勾 配は $0.0001 \cdot k$ としたBi-Linearモデルとする。

数值解析結果より、Fig.7に示すように抵抗モーメントが一定と なった $R=1 / 30 \mathrm{rad}$.時の值を $M_{p}$ として、 $Z_{p x y}=M_{p} / \Delta P_{V}$ を求めた。数值 解析では、釘の降伏曲面を12分割のM.S.S.モデルで近似表現して いること、長辺 1 辺のみ釷打ちする山の字釷配列では $R=1 / 30 \mathrm{rad}$. 時に全塑性状態とならないため、理論式から算出された $Z_{p x y} よ り も$ 低くなる傾向にある。

\section{3. 弾性時の $\alpha_{x}$ と中立軸位置を用いることの妥当性の検討}

対称釬配列の場合は、終局状態に至るまで中立軸位置の移動は生 じないので、未知数は $\alpha_{x}$ のとなる。X方向とY方向の回転剛性は 直列関係となるので、塑性化の進行に伴う回転剛性の低い方向の変 形の増大の影響を、回帰式では式(15)で表現されている。また、対 称性の悪い釷配列ほど、塑性化に伴う中立軸位置の移動量は大き く、回帰式ではその影響を式(16)で表されている。

そこで、代表的な釘配列に対して、未知数の変動に対する $Z_{p X Y}$ へ の影響を調へ、弾性時の $\alpha_{x}$ と中立軸位置の值を用いた場合に対する 比率をTable 2 に示す。表中の $y_{0} / H=0.387$ と 0.363 はそれぞれ弾性時 と式(15)または式(16)による全塑性時の值である。同表 (a)では、 中立軸位置の変動がなく $\alpha_{x}$ のみが変動する釘配列の例を、同表(b) では中立軸位置も変動する釷配列の例を示している。同表 (a)で は、参考值として数值解析で $R=1 / 30 \mathrm{rad}$. 時の変形から求めた $\alpha_{x}$ (N.A.) の值も示してある。同表 (a)に見られるように、 $\alpha_{x}$ の変動と 比べて $Z_{p x y}$ の変動幅は極めて小さい。その理由は、釘の滑り量は、 $\alpha_{x}$ の変動によって変形が減少した方向と増加した方向のベクトルの 成分を式 (5)で合成されるため、結果として合成されたベクトルの 大きさの変化が少なくなるためである。また、同表 (b)に見られる ように、塑性化に伴う中立軸位置の移動の影響も極めて少ない。し たがって、未知数である $\alpha_{x}$ と中立軸位置の值に、弾性時の值を用い て計算しても $1.5 \%$ 以内の誤差に収まっており、問題ないと判断で きる。

\section{5. まとめ}

本論文で得られた知見を以下に示す。

1. 任意の釷配列で打たれた面材壁の全塑性釷配列係数 $Z_{p x y}$ の算
定式を上界定理を用いて理論的に誘導した。

2. 計算の際の未知数である $\alpha_{x}$ と中立軸位置は、弾性時の值を用 いても、誤差は $1.5 \%$ 以と極めて少ない。

3. 実務で多用寸る釘配列に関しては、回帰式から求まる $Z_{p x y}$ の 理論值との誤差は $5 \%$ 以内である。回帰式では $5 \%$ 下限值とす るために低減係数0.9411を乗じており、実際に使用する面材 の釘配列では、回帰式による $Z_{p x y}$ は、理論值に対して最大で 約 $10 \%$ 過少評価している釷配列が存在する。

4. 回帰式では $Z_{p x y}$ が $Z_{x y}$ を下回る例が存在することを示した。

5. 理論式に対して、M.S.S.モデルによる数值解析結果はやや下 回る傾向にある。

回帰式による全塑性釷配列係数 $Z_{p x y}$ の算定式は、力学的根拠に乏 しく、また、計算が煩雑な割に、使用頻度の高い面材の釷配列では 過小評価となるなど計算精度も良くない。そのため、筆者は実務に おいて、回帰式の代わりに本理論式を用いることを強く推奨する。

\section{謝辞}

数值解析に際しては、株式会社エヌ・シー・エヌ 小谷竜城氏の 協力を得ました。ここに記して感謝の意を表します。

\section{参考文献}

1) Murakami M. Inayama M.: Formulae to Predict the Elastic and Plastic Behavior of Sheathed Walls with any nailing Arrangement Pattern, Journal of Structural and Construction Engineering (Transactions of AIJ), No.519, pp.87-93, 1999.5 (in Japanese) 村上雅英, 稲山正弘: 任意の釷配列で打たれた面材壁の弾塑性挙動の予測 式，日本建築学会構造系論文集，第519号，pp.87～93, 1999.5

2) Japan Housing and Wood Technology Center: Allowable Stress Design of Wooden Houses with Post and Beam Construction System 2017, pp.198, 203, 2017.3 (in Japanese)

日本住宅・木材技術センター:木造軸組工法住宅の許容応力度設計 2017 年 度版, pp.198-203, 2017. 3

3) Azumi.Y. Murakami M.: Prediction of the Performance of Sheathed Shear Elements Reinforced with Shear Keys along Panel Joints and It's Verification with Numerical Analyses, Journal of Structural and Construction Engineering (Transactions of AIJ), No.707, pp.93-103, 2015.1 (in Japanese)

安曇良治, 村上雅英: 面材の継ぎ目に沿ってせん断キーで補強した面材張 り耐力要素のせん断性状の推定と数值解析による検証, 日本建築学会構造 系論文集, 第707号, pp.93 103、2015. 1

4) Tuomi.L. and McCutcheon W.J.: Racking Strength of Light-Frame Nailed Walls. Journal of the Structural Division, Proceedings of the ASCE, Vol.104. ST7, pp.1131-1140, 1978.7

5) Kamiya F.: Theoretical Studies on Racking Stiffness and Strength of Wooden Sheathed Walls, Transactions of the Architectural Institute of Japan, No.309, pp.86-91 1981.11 (in Japanese) 神谷文夫：面材を釘打ちした耐力壁のせん断剛性及び強度に関する理論的 研究, 日本建築学会論文報告集, 第309号, pp.86〜91. 1981.11

\section{注}

注1）仮定を満たす具体的な仕様は、文献2に記載されている。

注2） $I_{x}=I_{y}$ の場合、塑性化に伴う変形の局所化は生じないが、式(15)では $\theta_{p x}=1.28458 \cdot \theta_{p y}$ となっており、明らかに実現象とは矛盾している。その 原因は筆者が回帰式を作成する際のミスに起因していたことが、今回の 検討で見いだされた。しかしながら、そのような場合であっても、式 (17)が機能して必要な計算精度は確保できている。ちなみに、Table 1に 示すNo.1における式(15)を用いた回帰式による計算值の理論值に対する 誤差は0.968である。 


\section{THEORETICAL FORMULA TO PREDICT THE ULTIMATE SHEAR CAPACITY OF SHEATHED SHEAR WALLS WITH ANY NAILING ARRANGEMENT PATTERN}

Comparison between values calculated from theoretical equations and regression equations

\section{Masahide MURAKAMI*1}

\footnotetext{
${ }^{1}$ Prof., Faculty of Architecture, Dept. of Architecture, KINDAI Univ., Dr.Eng.
}

The formula for the full plastic nail arrangement modulus $Z_{p x y}$ which is used in calculating ultimate shear capacity $M_{p}$ of the sheathed shear walls with any nail arrangement was theoretically derived using the upper bound theorem.

The unknown values are the rotation ratio $\left(\theta_{x} / \theta_{y}\right)$ and the neutral axis positions $\left(x_{o}\right.$ and $\left.y_{o}\right)$ in the calculation.

The difference between the calculation with the elastic values and the plastic values as unknown values is within $1.5 \%$.

The derived formula Eq.(6) provides the theoretical values of the ultimate moment capacity $Z_{p x y}$ of sheathed shear walls.

$M_{p}=\Delta P_{v} \cdot \sum \sqrt{\left\{\left(y_{j}-y_{o p}\right) \cdot \alpha_{x}\right\}^{2}+\left\{\left(x_{i}-x_{o p}\right) \cdot\left(1-\alpha_{x}\right)\right\}^{2}}=\Delta P_{v} \cdot Z_{p x y}$

with $x_{j}$ and $y_{i}$ the co-ordinate of ij -th nail, $x_{o p}$ and $y_{o p}$ the neutral axis position in the $\mathrm{X}$ and $\mathrm{Y}$ directions shown in Fig. 4 , $\Delta P_{v}$ the yield shear force of nails in Fig.1, and $\alpha_{x}$ the rotation angle ratio given in Eqs. (7) - (11).

The values of $Z_{p X y}$ obtained from the numerical analyses and the equations obtained from the regression analysis are compared to theoretical values. The values of $Z_{p x y}$ obtained from equations with the regression analysis are always smaller than theoretical values and are $10 \%$ smaller at the maximum.

The equation obtained from the regression analysis gives unreasonable values of $Z_{p x y}$. For example, $Z_{p x y}$ becomes smaller than $Z_{x y}$ in a few cases of nail arrangement. The values of $Z_{p x y}$ obtained from numerical analyses are smaller than the theoretical values. 